\title{
Kan det være Lyme-nevroborreliose?
}

Borreliabakterier kan overføres til menneske ved flåttbitt og gi opphav til Lyme-nevroborreliose. Sykdommen arter seg forskjellig med hensyn til symptomer og tidsforløp. De fleste pasientene har subakutt innsettende nevrologiske symptomer som oppstår uker til måneder etter infeksjon. Det vanligste er facialisparese eller fokale nevrogene smerter på grunn av radikulitt $(1,2)$. Andre symptomer kan være dobbeltsyn, nedsatt hørsel, lammelser, endret hudfølelse, gangvansker eller kognitive vansker. I sjeldne tilfeller har pasientene langvarige nevrologiske symptomer som progredierer over måneder og år, såkalt senfasesykdom. Klinisk nevrologisk undersøkelse viser oftest objektive funn, men radikulitter kan i tidlig fase arte seg som rene smertetilstander. Spinalvæskeundersøkelse viser inflammasjonstegn med forhøyet antall lymfocytter (3). De aller fleste pasientene med symptomvarighet over to måneder har antistoffer mot borreliabakterien i serum og spinalvæske (2). Påvisning av borreliantistoffer er imidlertid ikke tilstrekkelig til å stille diagnosen. Opptil 18\% av friske mennesker har antistoffer i serum (4), og en del har antistoffproduksjon i spinalvæsken, uten forhøyet lymfocyttall. Noen av disse er tidligere behandlet for sykdommen eller infeksjonen har gått spontant tilbake.

Kroniske og diffuse smerte- og tretthetstilstander med uspesifikke nevrologiske symptomer er vanlig i befolkningen. Slike symptomer er ikke typisk for nevroborreliose, men en artikkel i dette nummer av Tidsskriftet viser at pasientene ofte blir utredet for denne tilstanden (5). I Aust-Agder ble det i 2015 henvist 140 personer til spinalpunksjon med spørsmål om Lyme-nevroborreliose. Omkring én av fire hadde borreliaantistoffer i serum. Kun 30 av de 140 hadde typiske symptomer på Lyme-nevroborreliose. 110 hadde uspesifikke symptomer, hvorav halvparten hadde hatt disse i mer enn seks måneder. Denne liberale utredningspraksisen kan ha sammenheng med mye oppmerksomhet omkring flåttoverførte sykdommer generelt. Medieoppslag basert på enkelthistorier kan skape et inntrykk av at borreliainfeksjoner er en vanlig årsak til kroniske symptomer som man ikke finner annen forklaring på.

I undersøkelsen fra Aust-Agder fikk ingen av dem med langvarige uspesifikke symptomer påvist Lyme-nevroborreliose ved spinalpunksjon. Svakheter ved undersøkelsen er at det ikke systematisk ble gjort klinisk nevrologisk undersøkelse før spinalpunksjon og at antallet pasienter var for lavt til at man kan si noe sikkert om den diagnostiske nytteverdien av den. Men funnet er i tråd med den samlede kliniske erfaring at det er lav sannsynlighet for Lymenevroborreliose ved langvarige uspesifikke symptomer $(6,7)$. Spinalpunksjon for å utelukke sykdommen er unødvendig hos denne gruppen dersom det ikke kan påvises borreliaantistoffer i serum. Ved positiv serumprøve bør det gjøres spinalpunksjon dersom klinisk undersøkelse ikke kan utelukke nevrologisk affeksjon.

En liberal utredningspraksis fører til at vi ofte står overfor pasienter med uspesifikke symptomer og positiv antistofftest. Det er da rom for tvil, og dette er det viktig å formidle til pasienten. For det første er det en liten mulighet for aktiv borreliainfeksjon i tidlig dissemine- ringsfase da uspesifikke symptomer kan være dominerende. Mange velger å gi en to ukers antibiotikakur for å sikre seg mot dette, men ved langvarige symptomer er det lite rasjonale for det. For det andre kan den positive antistofftesten være et tilfeldig funn. I en undersøkelse av ca. 1200 norske blodgivere fant man for eksempel ingen sammenheng mellom subjektive helseplager og borreliaantistoffer i serum (8). For det tredje kan antistoffene være en markør på senfølger etter tidligere behandlet eller ikke-erkjent borreliainfeksjon, såkalt post-Lyme-sykdom. Begrepet er basert på at en del pasienter etter avsluttet behandling rapporterer om vedvarende uspesifikke helseplager $(6,9)$. Forekomsten av post-Lyme-sykdom er omdiskutert og mekanismene ukjente (7). Overfor den enkelte pasient bør man være åpen for denne muligheten, men det er viktig å formidle at symptomene ikke skyldes aktiv infeksjon og at langvarig antibiotikabehandling ikke har effekt (10).

Det er altså svært lav sannsynlighet for at kroniske uspesifikke nevrologisk symptomer uten objektive funn ved klinisk nevrologisk undersøkelse skyldes aktiv Lyme-nevroborreliose, selv om det blir påvist borreliaantistoffer i serum eller antistoffer i spinalvæske uten forhøyet celletall. Pasientene bør informeres om andre mer sannsynlige forklaringer på et positivt antistoffsvar for å unngå usikkerhet og feilbehandling med antibiotika.

\section{Åse Mygland \\ ase.mygland@sshf.no}

Åse Mygland (f. 1958) er spesialist i nevrologi, overlege ved Nevrologisk avdeling, Sørlandet sykehus, og professor II ved Universitetet i Bergen. Forfatter har fylt ut ICMJE-skjemaet og oppgir ingen interessekonflikter.

\section{Litteratur}

1. Ljøstad U, Skogvoll E, Eikeland R et al. Oral doxycycline versus intravenous ceftriaxone for European Lyme neuroborreliosis: a multicentre, non-inferiority, double-blind, randomised trial. Lancet Neurol 2008; 7: 690-5

2. Stanek G, Wormser GP, Gray J et al. Lyme borreliosis. Lancet 2012; 379: 461-73.

3. Mygland A, Ljøstad U, Fingerle $V$ et al. EFNS guidelines on the diagnosis and management of European Lyme neuroborreliosis. Eur J Neurol 2010; 17: 8-16, e1-4.

4. Mygland A, Skarpaas T, Ljøstad U. Chronic polyneuropathy and Lyme disease. Eur J Neurol 2006; 13: 1213-5.

5. Roaldsnes E, Eikeland R, Berild D. Lyme-nevroborreliose ved uspesifikke nevrologiske symptomer. Tidsskr Nor Legeforen 2017; 137: 101-4.

6. Hu LT. Lyme Disease. Ann Intern Med 2016; 165: 677.

7. Koedel U. Pfister HW. Lyme neuroborreliosis. Curr Opin Infect Dis 2017; 30: 101-7.

8. Hjetland R, Reiso H, Ihlebæk C et al. Subjective health complaints are not associated with tick bites or antibodies to Borrelia burgdorferi sensu lato in blood donors in western Norway: a cross-sectional study. BMC Public Health 2015; 15 : 657.

9. Eikeland R, Mygland A, Herlofson K et al. European neuroborreliosis: quality of life 30 months after treatment. Acta Neurol Scand 2011; 124: 349-54.

10. Berende A, ter Hofstede HJ, Vos FJ et al. Randomized Trial of Longer-Term Therapy for Symptoms Attributed to Lyme Disease. N Engl J Med 2016; 374: $1209-20$. 